\title{
Technological Evolution of Historic Structural Mortars
}

\author{
Vasiliki Pachta, Maria Stefanidou, Stavroula Konopisi and Ioanna Papayianni \\ Department of Civil Engineering, Aristotle University of Thessaloniki, Thessaloniki 54124, Greece
}

\begin{abstract}
Mortars are among the first building materials used in constructions, even from prehistoric times (8th millennium BC). Their study reveals a great source of information regarding the evolution of their technological characteristics and application techniques, the availability and exploitation of raw materials, as well the wider socio-economic aspects of each era. The aim of this paper is to comparatively evaluate the analysis results from approximately 1,000 structural mortar samples taken from various monuments and historic buildings of Greece, dated from the Hellenistic period, until the beginning of the 20th century. The analysis focused in the determination of their physico-mechanical and chemical properties, such as porosity, apparent specific gravity, mechanical strength, aggregates type and granulometry and chemical composition. Through the results' evaluation, significant remarks can be made upon the evolution of the raw materials used (binding system, aggregates, additives), as well as regarding the final properties of historic structural mortars. It is concluded that hydrated lime was the main binding agent used for a long-lasting period of 2.5 millenniums, while mixed type binding systems based on lime and natural pozzolan were systematically used for producing durable mortars, resistant to humidity. In any case, it seems that ancient masons were fully aware of the significant role of mortars in constructions and were capable of exploiting the available raw materials and application techniques to the maximum.
\end{abstract}

Key words: Structural mortars, technological evolution, physico-mechanical, chemical properties.

\section{Introduction}

The first use of structural mud-mortars in rubble and adobe masonry is dated from the 8th millennium $\mathrm{BC}$ in Mesopotamia and Babylonia, where they usually had similar characteristics with mud bricks (they both came from the same raw material, with a different elaboration) [1, 2]. In Greece, the first examples are dated during the 6th millennium $\mathrm{BC}$ in the Neolithic settlements of Sesklo and Dimini [3]. Mud-mortars were manufactured nearby the construction work and clay was often mixed with organic (herbs, roots, straw and reeds) and inorganic (sand, gravel) additives, in order to increase mass stability and durability $[1,4]$.

Due to their importance in constructions, mortars' technology and application has been thoroughly studied by ancient writers [5]. Aristotle (384-322 BC) [6], Theophrastos (372-287/5 $\quad$ BC) [7], Stravon (63/64BC-23AD) [8], Pliny (23-79AD) [9] and

Corresponding author: Vasiliki Pachta, Dr., research fields: historic mortars, repair materials for the restoration of historic structures. E-mail: vpachta@civil.auth.gr.
Dioskouridis (40-90AD) [10] mainly referred to the binding agents of mortars, such as lime $[6,10]$ and pozzolan [6-9]. Vitruvius (authorship 27-23BC) [11] was the first writer who gave specifications about the selection of raw materials, as well as the manufacture and application of mortars, according to their functional role (structural, renders and floor substratum's). Posterior writers, such as Leon Battista Alberti (1404-1472) [12], Andrea Palladio (1508-1580) [13] and Cennino d' Andrea Cennini (15th C AD, 2nd half) [14] gave also specifications, based on ancient literature [5].

The period of the first use of lime in structural mortars, has not been yet well testified. Writers indicate possible dates, such as Davey [15], according to whom, at least from 2,450 BC (when a lime kiln in Khafaje was dated) started the use of lime combined with clay, ash and asphalt in mortars. In Greece, in Akrotiri of Thera (1,700-1,400 BC), structural mortars were made of local origin clay, mixed with gravel, charcoal and straw [16]. These joints stopped 2-3 cm below surface and this gap was covered with lime 
mortar which was externally engraved [16].

The systematic use of lime in Greece appeared in parallel with the use of clayish material or pozzolan (santorine earth) and is dated from the Archaic and Classic Antiquity [10, 17-20]. Cisterns are mainly referred by researchers, as those in Thira [10], Kamiros of Rhodes (middle 6th C BC) [17, 18], Lavrion (5th C BC) [19], as structures in which lime-pozzolan have been used, as well as high proportion in coarse aggregates (gradation 0-20 mm).

In Olynthos (Classic period, 5th C BC), structural mortars were also lime based with an addition of clayish material, but in parts of the walls that were in contact with water, pozzolan was added in order to increase their impermeability [20]. The aggregates were of natural (river) origin, of $0-8 \mathrm{~mm}$ gradation and in a $\mathrm{B} / \mathrm{A}$ ratio $1 / 2$ [20].

In Hellenistic monuments such as Dilos residences (2nd C BC) [10], ancient theatre of Argos (3rd C BC) [5], archaeological site of Loggos (4th C BC) [21], lime-pozzolan mortars were mainly found, with aggregates of natural origin and of granulometry mainly 0-8 mm (Fig. 1a).

During Roman period (2nd C BC-3rd C AD), the use of lime and pozzolan dominated in constructions, while brick dust and crushed brick also started to be used [21, 22] (Fig. 1a). According to Vitruvius $[11,23]$, structural mortars were made of 1 part of lime and 3 parts of river sand, or 1 part of lime, 2 parts of river sand and 1 part of crushed brick. In Galerious Palace (Thessaloniki, 3rd C AD) structural mortars consisted of lime, pozzolan and natural aggregates (gradation $0-8 \mathrm{~mm}$ ) in a B/A ratio of $1 / 2$ to $1 / 2.5$, while in some cases brick dust and crushed brick were also detected (Fig. 1b) [21].

The systematic and in high proportion use of brick dust and crushed brick in lime or lime-pozzolan mortars was expanded during the Byzantine era (4th-15th C AD) [24-26] (Fig. 1b). Structural mortars were characterized by a reddish color, low specific density, high durability and impermeability, as well as a great thickness of joints $(2-5 \mathrm{~cm}$ even $6 \mathrm{~cm})$ (Fig. 2) [27].
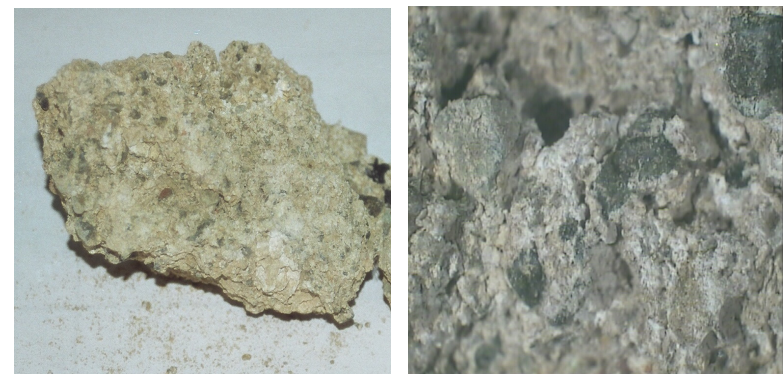

(a)
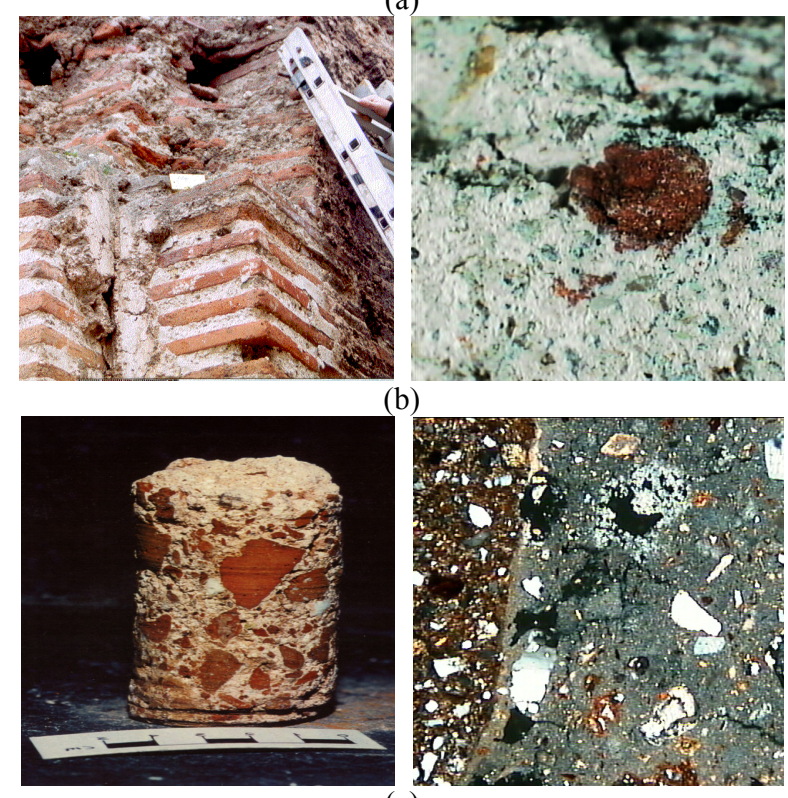

(b)

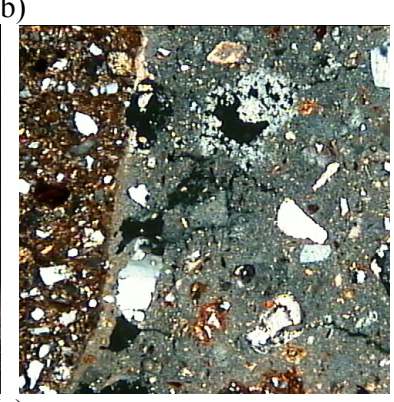

(c)
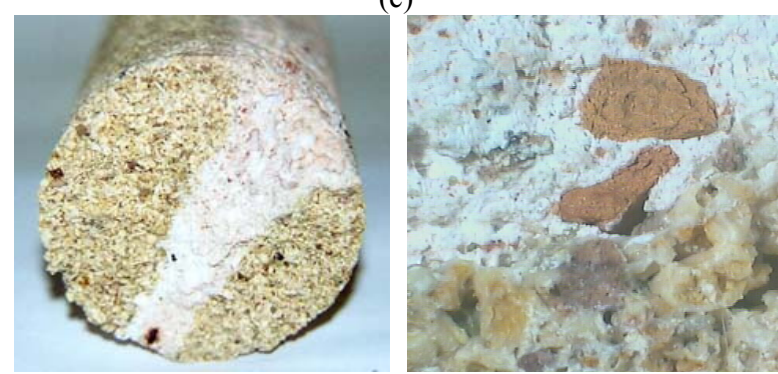

(d)
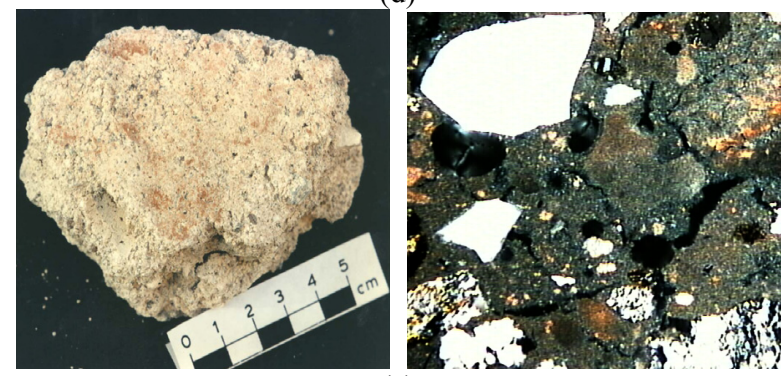

e)

Fig. 1 Macroscopic and microscopic photos of structural mortars from various historic periods: (a) Hellenistic (Archaeological site of Loggos, 4th C BC); (b) Roman (Galerius Palace, 3rd C AD); (c) Byzantine (Saint Sophia, Thessaloniki, 8th C AD); (d) Ottoman (Bezesteni, 15th C AD); (e) Medieval (Medieval city of Rhodes, 15th C AD). 


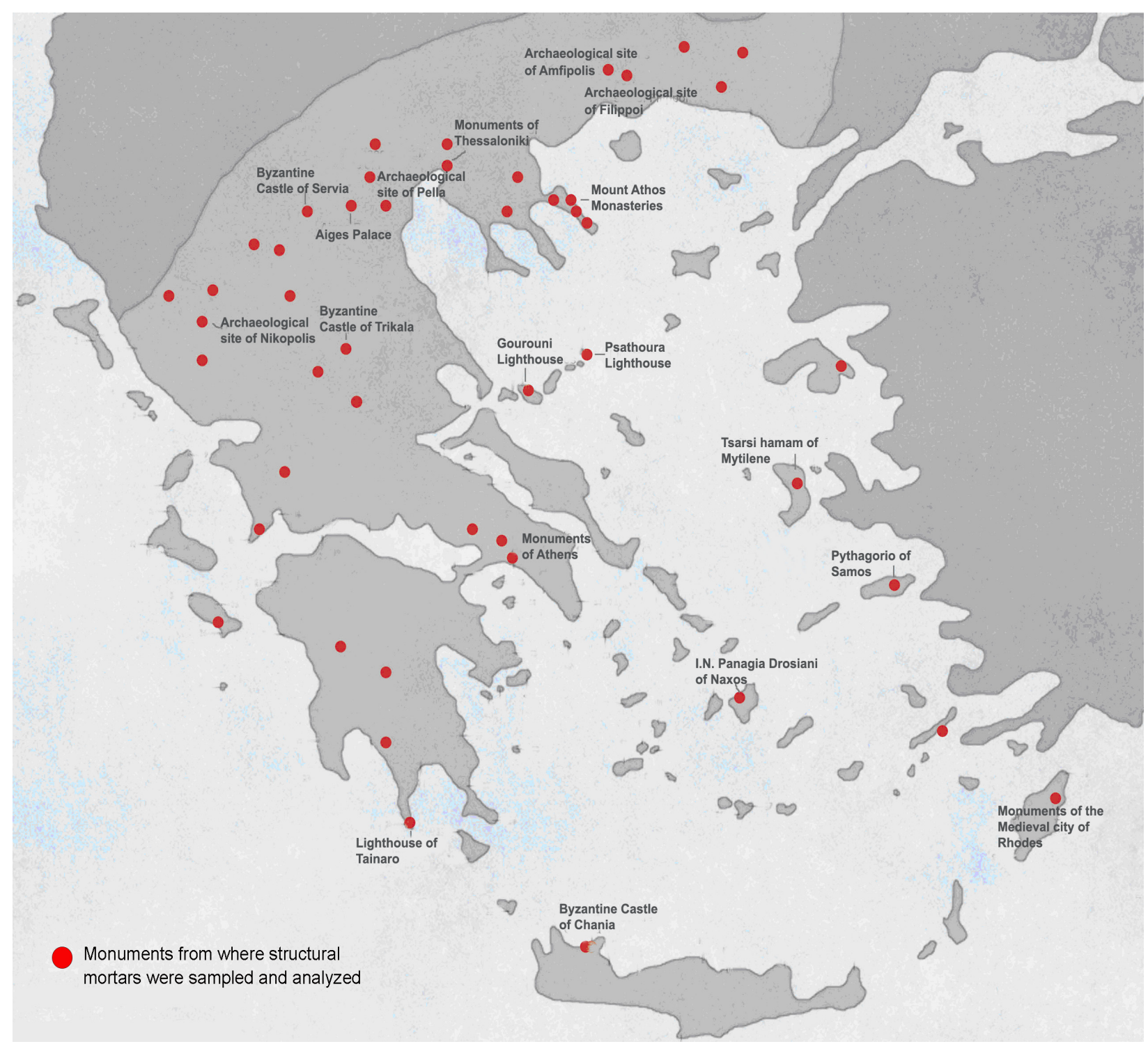

Fig. 2 Distribution of structural mortar sampling places in Greece.

Aggregates (natural origin and crushed brick) were of gradation $0-8 \mathrm{~mm}$ to $0-16 \mathrm{~mm}$, with a $\mathrm{B} / \mathrm{A}$ ratio $1 / 2$ to $1 / 3$ [5, 24-27]. It is remarkable, as shown in Fig. 1c, the good adhesion between the binder paste and the crushed brick aggregates.

During the Ottoman period (15th-19th C AD) structural mortars were manufactured by using often the available raw materials [5]. They were mainly lime based (pure lime or lime with clay), while in specific constructions which demanded in resistance to humidity (baths, cisterns), pozzolan and brick dust were also added [28, 29] (Fig. 1d). Aggregates were of natural origin (in some cases crushed brick was also added), of 0-8 $\mathrm{mm}$ granulometry and of $\mathrm{B} / \mathrm{A}$ ratio $1 / 2$ [28, 29]. In Medieval (15th-19th C AD) Greek monuments (Dodecanese, Ionian islands, Crete), structural mortars mainly consisted of lime (in some cases pozzolan was added), natural or crushed aggregates and crushed brick in gradations $0-4 \mathrm{~mm}$ to 0-8 $\mathrm{mm}$ and $\mathrm{B} / \mathrm{A}$ ratio $1 / 1$ to $1 / 2$ [5, 21, 30] (Fig. 1e). As proved from nowadays survey, these mortars had exhibited good resistance to marine environment, to which have exposed for centuries.

During the 19th and beginning of the 20th century, 
structural mortars varied depending on the building type and the local constructional tradition. Private houses, usually presented mortars based in lime, clay or both [5]. In significant buildings (villas, public buildings) mortars were of higher quality and consisted of lime and pozzolan [31, 32]. Aggregates, in all cases, were usually of natural origin and of 0-8 mm gradation $[31,32]$.

The aim of this paper is to comparatively study the physico-mechanical and chemical properties of structural mortars taken from various monuments and historic building of Greece, throughout a large period starting from the Hellenistic period, until the beginning of the 20th century. All results were statistically evaluated in order to proceed to safe conclusions regarding the evolution of the consistency and structure of historic mortars throughout 2.5 millenniums.

\section{Materials and Methods}

During the last twenty years more than 1,000 historic structural mortars were analyzed according to a holistic methodology developed in the Laboratory of Building Materials of the Aristotle University of Thessaloniki [5, 22-24]. According to the methodology, the microstructural, physico-mechanical and chemical characteristics of mortars were analyzed through a series of tests. Microstructure observation was performed with stereoscope (Leica Wild M10) assisted by image analysis (ProgRes), aggregates granulometry by sieving after decomposition and granulation of the original sample by hand (EN1015-1:1998), porosity and apparent specific gravity were according to RILEM CPC 11.3, while mechanical strength was evaluated in sound, modified samples by applying crushing test. Finally, wet chemical analysis assisted by atomic absorption was performed in a fine fraction of the sample $(<75 \mu \mathrm{m})$. $[33,34]$

The comparative study of this source of information emerged many difficulties, due to the high number of samples and the large range of results. An expert system was therefore designed in order to upload and manage the analysis results of mortars of various types, historic periods and monuments [5, 35]. Its main goal was to be easily applicable by any user, include a great number of results, allow statistical evaluation and permit modifications according to future needs.

The major outcome of the data system was that through the statistical analysis numerous conclusions could be extracted, regarding the technological characteristics of mortars (such as binder/aggregate ratio, aggregates' type and gradation, binder system, even pathology symptoms). Remarks in relation to other parameters, such as historic period, type of mortar, type of monument could also be made.

In its present form the data base contains the analysis results of totally 1,000 structural mortar samples, taken from various monuments and historic buildings, spread out in all Greece (Fig. 2). The samples were taken from various monuments spread all over Greece and were dated from the Hellenistic period up to the beginning of the 20th century, when cement and concrete started to prevail in constructions. Fig. 3, depicts the samples' range according to the era to which they are dated.

\section{Experimental Analysis and Results}

The conclusions deriving from the statistical evaluation of the results concerning structural mortars could be endless, according to the parametric classification and the needs of each user [5]. In this paper, only some indicative observations are presented regarding the binding system, the aggregates' granulometry and the presence of inclusions.

\subsection{Binding System}

Based on the evaluation of the results of chemical composition it seems that structural mortars are mainly lime based throughout all historic periods (Fig. 4). A 


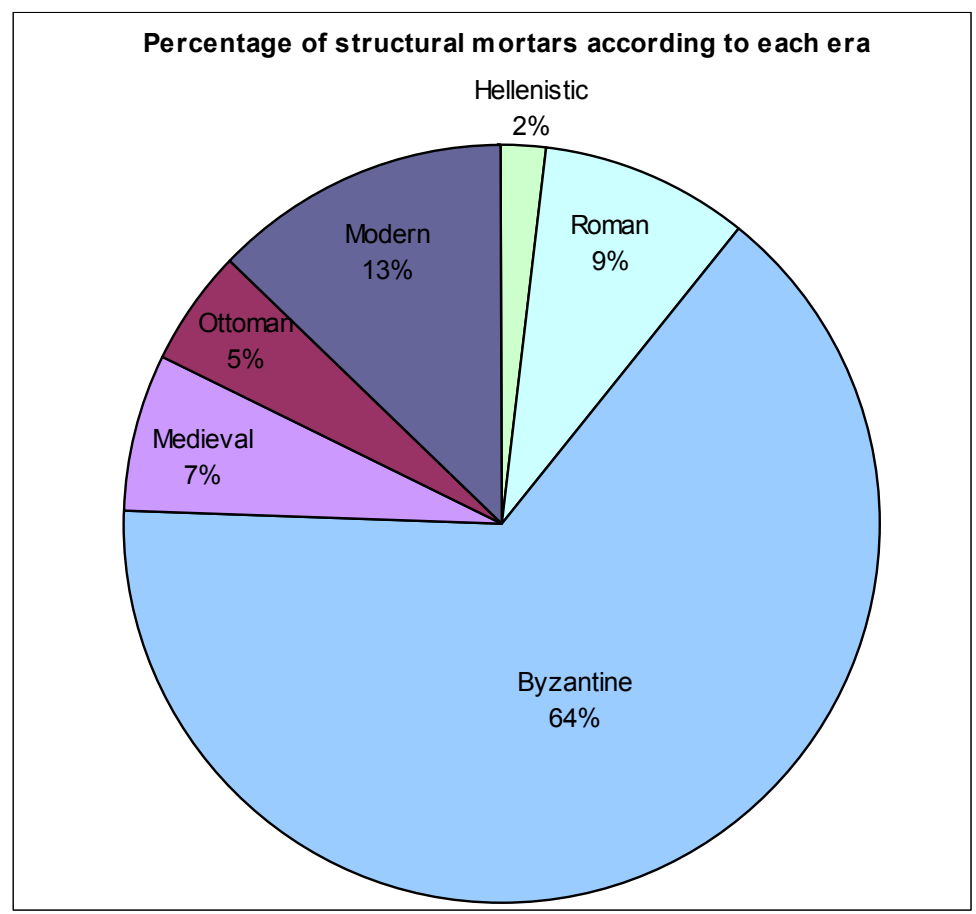

Fig. 3 Distribution of structural mortar samples according their historic period (total number of analyzed samples 982).

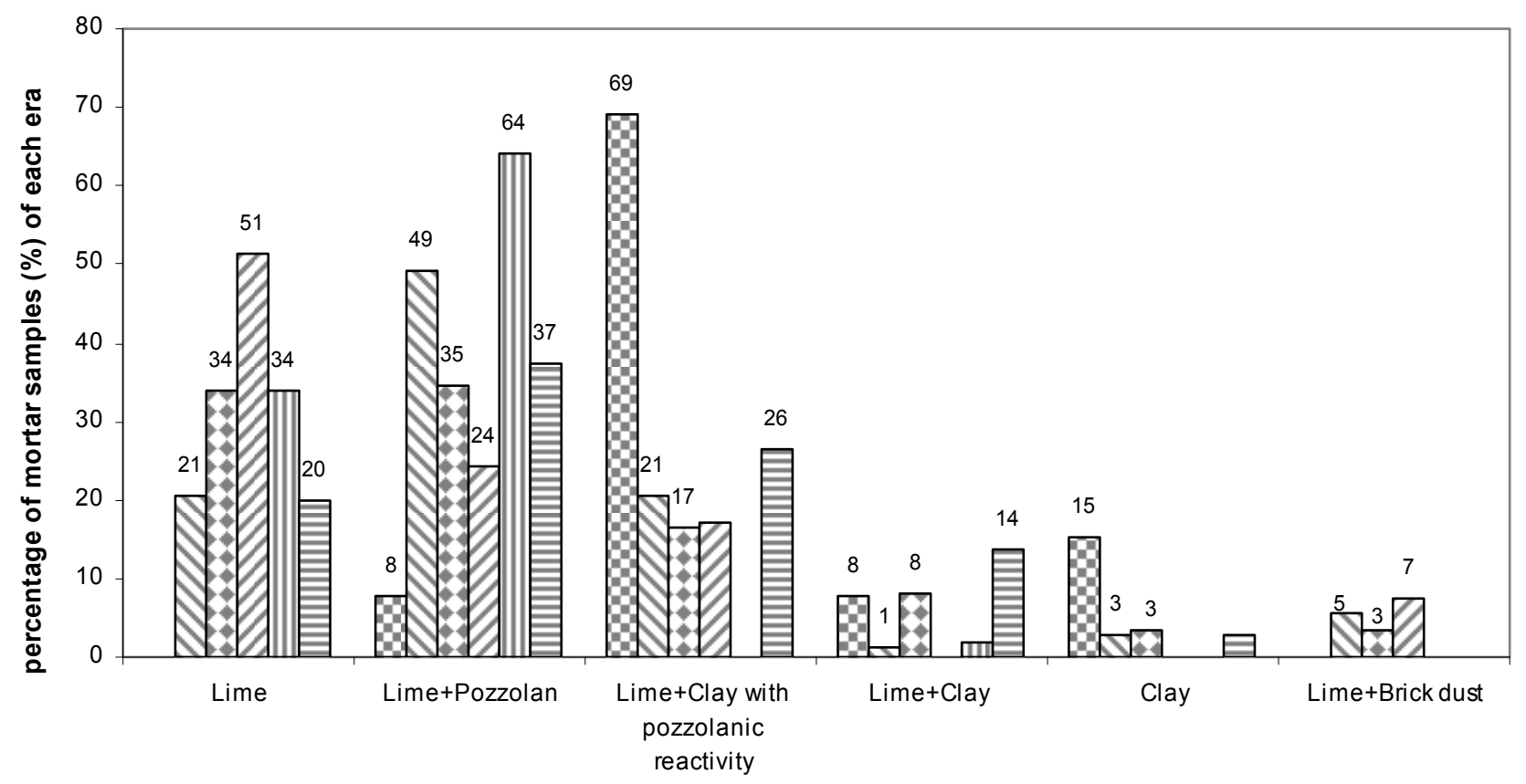

$\square$ Hellenistic $\square$ Roman $\square$ Byzantine $\square$ Ottoman $\square$ Medieval $\boxminus$ Modern

Fig. 4 Binding systems of structural mortars of different historic periods.

mixed type binding system (lime + pozzolan) has been used even from the Hellenistic period. These represent the $8 \%$ of the total number of the samples dated from that period. The highest percentage of Hellenistic mortars $(69 \%)$ consisted of lime + clayish material with pozzolanic reaction. The use of pure lime mortars is firstly presented during Roman times ( $21 \%$ of the total number of Roman samples), while the highest 
percentage of Roman structural mortars contain lime + pozzolan. Brick dust also starts to be used in the matrix during Roman period (5\% of the total number of Roman samples consist of lime + brick dust) and its use continues until Byzantine and Ottoman period. In Byzantium, mainly lime mortars (34\% of the total number of Byzantine samples) and lime + pozzolan mortars $(35 \%$ from the total number of Byzantine samples) are used. Ottoman mortars are mainly composed of pure lime (51\% from the total number of Ottoman samples). In Medieval times, the highest percentage of mortars are lime + pozzolan ones $(64 \%$ of the total number of medieval samples). In modern pre-cement period the highest number of samples contain as binder pure lime $(20 \%)$ and lime + pozzolan (37\%).

\subsection{Aggregates' Granulometry}

Regarding the aggregates' granulometry of structural mortars (Fig. 5), it seems that the most often gradations are those of $0-6 \mathrm{~mm}$ and $0-8 \mathrm{~mm}$. Of course there are small scale differentiations, such as in the case of some Hellenistic mortars found which present a variety in granulometry from $0-2.5 \mathrm{~mm}$ to 0-16 mm, but mainly consist of aggregates $0-4 \mathrm{~mm}$ (38\% from the total number of Hellenistic mortars). Roman mortars mainly include $0-8 \mathrm{~mm}$ size aggregates (45\%), while those of $0-6 \mathrm{~mm}$ and $0-16 \mathrm{~mm}$ size have also been found $(20 \%$ and $26 \%$, respectively). The same remark seems to be asserted for Byzantine mortars. Ottoman mortars comprise mainly $0-6 \mathrm{~mm}$ aggregates ( $46 \%$ of the total Ottoman samples). In medieval mortars, a wider range from 0-1 $\mathrm{mm}$ to $0-16 \mathrm{~mm}$ aggregate gradations have been found. Modern mortars consist of aggregates of $0-2.5 \mathrm{~mm}$ to 0-16 mm.

\subsection{Presence of Inclusions}

The use of additives, as a mean to improve mortars' properties in fresh and hardened state, is usual in all historic periods $[5,36]$. However, the microstructural study of mortars shows that apart from the inclusions that were deliberately inserted in the mass, there are others that can be characterized as impurities of raw materials. The main inclusions that have been observed during the analysis of the mortar samples

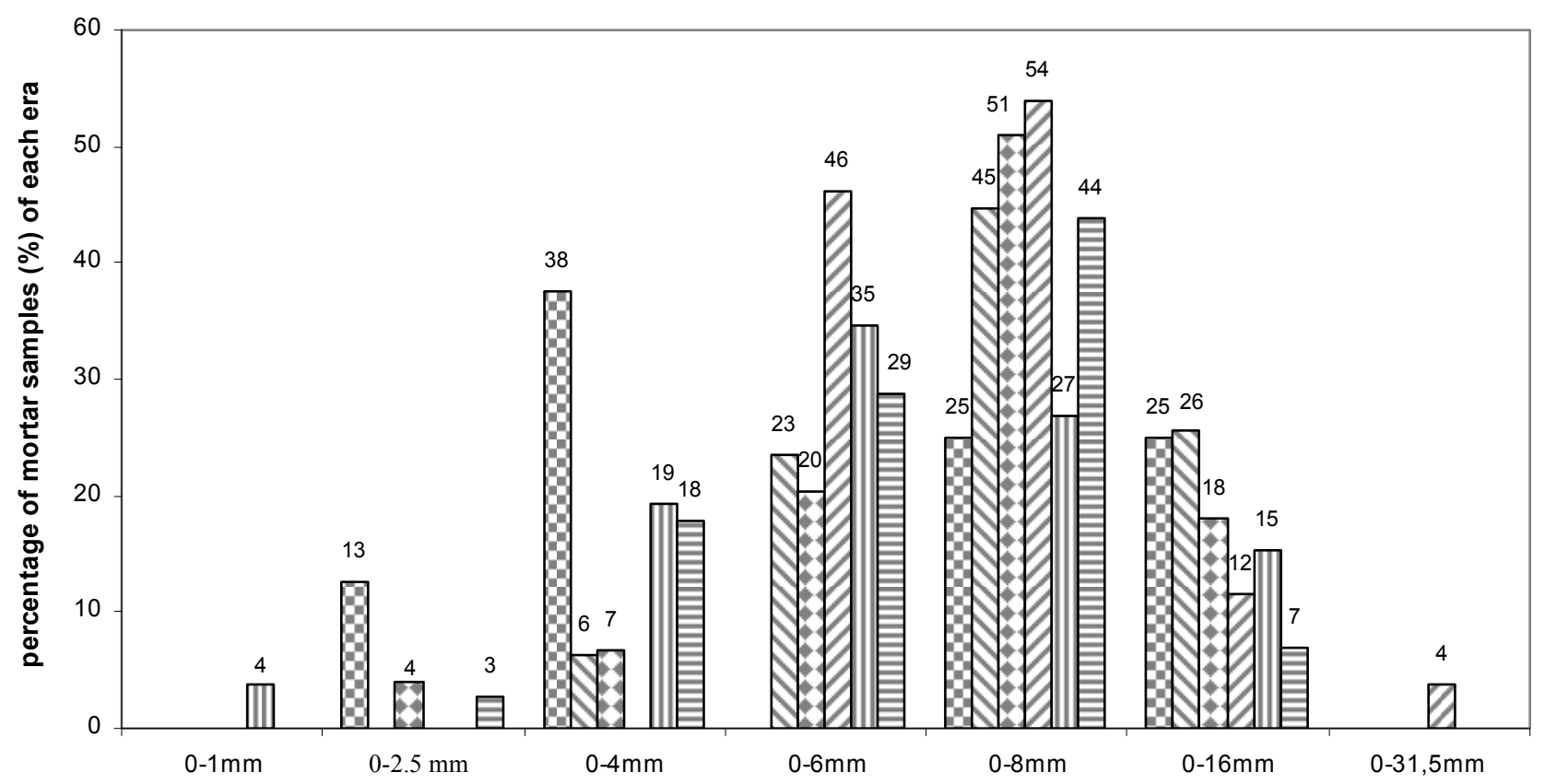

$\square$ Hellenistic $₫$ Roman $\square$ Byzantine $\square$ Ottoman $\square$ Medieval $\boxminus$ Modern

Fig. 5 Aggregates granulometry of structural mortars of different historic periods. 


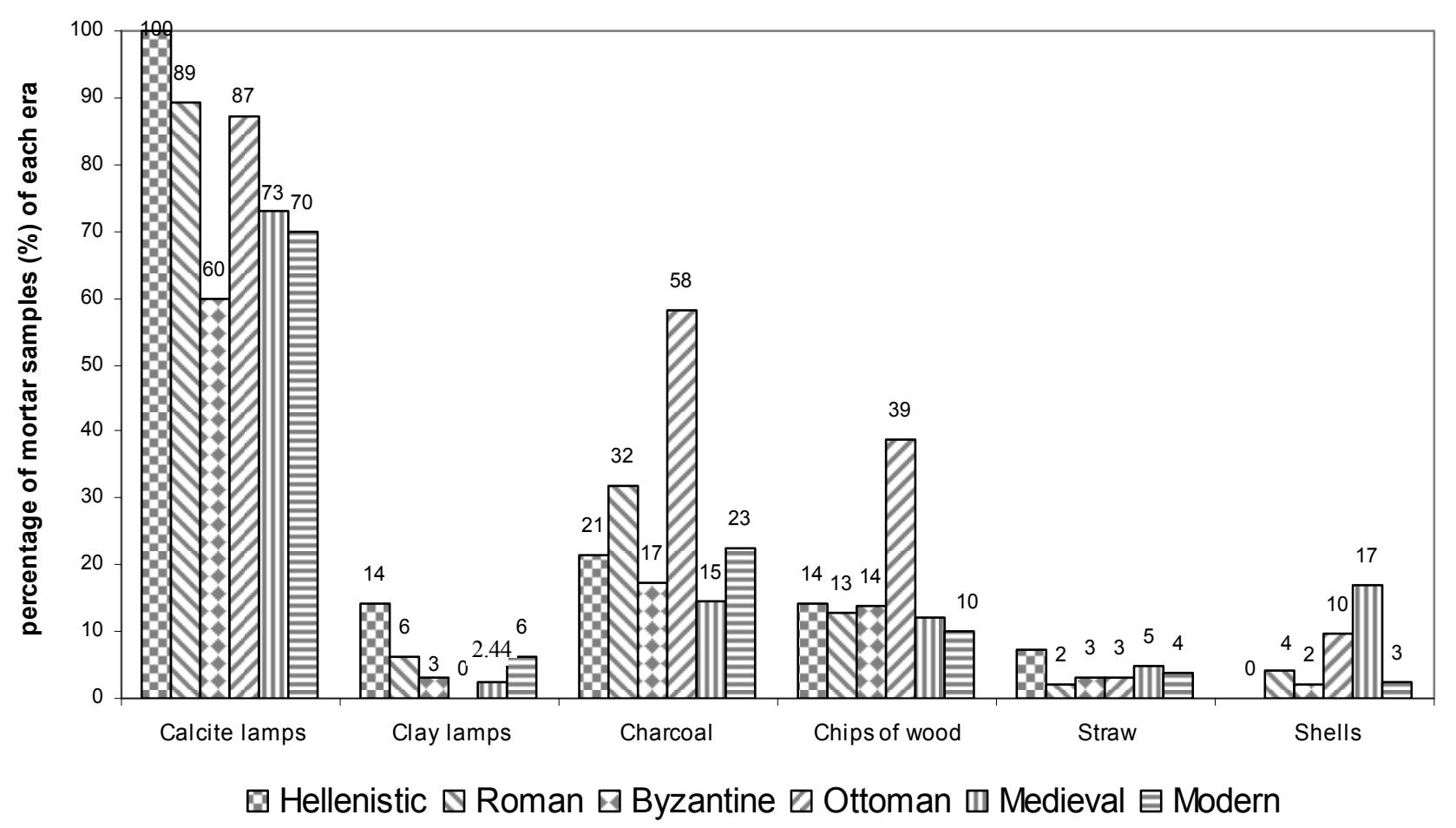

Fig. 6 Presence of inclusions in structural mortars of different historic periods.

were: calcite lumps, clay lumps, charcoal, chips of wood, straw and shells (Fig. 6). Calcite lumps were usual in all eras, since they were found in the majority of the analyzed structural mortars. Their presence can be attributed to the lime grain accumulation during slaking. On the other hand, clay lumps were scarcely found (apart from mortars of the Hellenistic period) and can be interrelated to the use of clay in the matrix and to inadequate mixing. Charcoal particles have been recorded in all eras (they mainly prevail in Ottoman mortars). Wooden fibers, in a measured proportion by mass, were also met in all periods (mainly in Ottoman), probably as a mean to increase the volume stability of mortars. The use of straw, for the same purposefulness, seems to be more limited. Finally shells were mainly found in Medieval times and can be attributed to aggregates, which were coming often from the sea in islands, without many other aggregate deposits.

\section{Conclusions}

From the survey and comparative study of technology of structural mortars, it seems that throughout centuries there is small variety of raw materials used. Clay was the first binding agent ever used, while gradually new binders, more resistant to humidity and capable of bearing higher loads were introduced. Lime, pozzolan and brick dust started to be used selectively in Hellenistic period and prevailed in Roman and Byzantine times, forming mixed type binding systems that were used until the beginning of the 20th century.

On the other hand, through the statistic evaluation of the analysis results, more precise pieces of information can be drawn regarding mortars' components and their mixing. For structural mortars, it seems that from the Hellenistic to pre-cement Modern period the same raw materials have been used. Lime is the main constituent, while mixed type binding systems based on lime + pozzolan are used for producing more durable mortars, resistant to humidity. The aggregates' granulometry varies from $0-2.5 \mathrm{~mm}$ to $0-31.5 \mathrm{~mm}(0-8 \mathrm{~mm}$ is the most usual). Inclusions have been found in all eras and can be either characterized as impurities of the raw materials, or as additives, used to improve mortars' properties. 
Synoptically, from the survey of historic mortars many conclusions could be extracted about their nature. The use of different binders was depending on the availability of raw materials and constructional tradition of its era. The need for more resistant mostly to moisture mortars, made ancient masons to extend their expertise by trying mixed type binders, various aggregate types and gradations and different inclusions.

\section{References}

[1] G.R.H. Wright, Ancient Building Technology, Materials, Part 1: Text, Brill, Leiden, Boston, 2005.

[2] O. Aurenche, The Eastern House, Edition P. Geuthner, Paris, 1981.

[3] C. Tsountas, The Pre-Historic Citadels of Dimini and Sesklo, Library of the Archaeological Society at Athens, Athens, 1908. (in Greek)

[4] Çatalhöyük Research Project, Archive report, Çatalhöyük, 2008.

[5] V. Pachta, Study of the technological evolution of mortars, Ph.D. Thesis, Department of Civil Engineering, Aristotle University of Thessaloniki, Thessaloniki, 2011.

[6] Aristotle, Meteorologika 1 and 2, Vol. 13-14, Edition O. Chatzopoulos, Athens, 1992. (in Greek)

[7] Theophrastos, Characters, On Piety, On Stones, On Fire, Edition O. Chatzopoulos, Athens, 1998. (in Greek)

[8] Stravon, Geographic, Vol. 8, Scientific Association of Greek Literature PAPYROS, Athens, 1962. (in Greek)

[9] Pliny, Natural History, Book 36, W. Heinemann Ltd., London, 1971.

[10] A.K. Orlandos, The Building Materials of Ancient Greeks, According to Writers, Inscriptions and Monuments: Part A, Vol. 2, Ancient Greek Architecture, Athens, 1958. (in Greek)

[11] P. Vitruvius, M.H. Morgan, Vitruvius: The Ten Books on Architecture, Dover Publications, New York, 1960.

[12] L.B. Alberti, J. Leoni, J. Rykwert, Ten Books on Architecture, Alec Tiranti, London, 1965.

[13] A. Palladio, The Four Books of Architecture, Dover Publications, New York, 1965.

[14] C.A. Cennini, D.V. Thompson, The Craftsman's Handbook, Dover Publications, New York, 1954.

[15] N. Davey, A History of Building Materials, Phoenix House, London, 1961.

[16] K. Palivou, Akrotiri of Thera: The Constructional Technology, Library of the Archaeological Society at Athens, Athens, 1999. (in Greek)

[17] E. Eustathiadis, Greek Concrete of Three Millenniums,
Technological Research, Athens, 1978.

[18] M. Koui, C.H. Ftikos, The ancient Kamirian water storage tank: A proof of concrete technology and durability for three millenniums, Materials and Structures 31 (1998) 623-627.

[19] C. Conophagos, H. Badeca, The water cisterns of ore washers in Laurion and their special hydraulic mortar, Hellenic Journal of Geosciences 6 (1974) 328-337.

[20] I. Papayianni, M. Stefanidou, Durability aspects of ancient mortars of the archaeological site of Olynthos, Journal of Cultural Heritage 8 (2007) 193-196.

[21] I. Papayianni, M. Stefanidou, Mortars for intervention in monuments and historical buildings, in: Transactions of the Wessex Institute, Chalkidiki, Greece, 2003, pp. 57-64.

[22] R. Bugini, A. Salvatori, Investigation of the characteristics and properties of "Cocciopesto" from the ancient Roman period, Conservation of Stone and Other Materials 1 (1991) 386-393.

[23] J.P. Adam, A. Mathews, Roman Building: Materials and Techniques, B.T. Batsford Ltd., London, 1994.

[24] I. Papayianni, M. Stefanidou, Repair mortars for monuments in Byzantine architecture, in: Proceeding of 5th International Congress on Restoration of Architectural Heritage, Firenze, 2000, pp. 1671-1683.

[25] I. Papayianni, K. Theocharidou, The longevity of the Byzantine church of Hagia Sophia in Thessaloniki, in: Proceeding of 6th CANMET-ACI International Conference on Durability of Concrete, Thessaloniki, 2003.

[26] A. Moropoulou, A.S. Cakmakb, G. Biscontinc, A. Bakolasa, E. Zendric, Advanced byzantine cement based composites resisting earthquake stresses: The crushed bricky lime mortars of Justinian's Hagia Sophia, Construction and Building Materials 16 (2002) 543-552.

[27] G. Baronio, L. Binda, C. Tedeschi, Thick mortar joints in Byzantine buildings: Study of their composition and mechanical behaviour, in: Proceeding of International Conference on Studies in Ancient Structures, Istanbul, 1997, pp. 235-244.

[28] I. Papayianni, Technology of mortars and bricks used in Ottoman monuments in Thessaloniki, in: Proceeding of International Conference on Studies in Ancient Structures, Istanbul, 1997, pp. 245-253.

[29] I. Papayianni, M. Stefanidou, Repair mortars suitable for interventions of Ottoman monuments, in: Proceeding of International Conference on Studies in Ancient Structures, Istanbul, 1997, pp. 255-264.

[30] P. Maravelaki-Kalaitzakia, A. Bakolas, A. Moropoulou, Physico-chemical study of Cretan ancient mortars, Cement and Concrete Research 33 (2003) 651-661.

[31] I. Papayianni, E. Nikitakos, A. Sioutis, V. Pachta, Study of the materials and pathology of the administrative 
building of Allatini miles, in: Proceeding of 3rd National Conference on Mild Interventions for the Preservation of Historic building, Thessaloniki, 2009. (in Greek)

[32] I. Papayianni, V. Pachta, Damages of old lighthouses and their repair, in: 1st International Conference on Construction Heritage in Coastal and Marine Environments, Damage, Diagnostics, Maintenance and Rehabilitation, Lisbon, 2008.

[33] I. Papayianni, The longevity of old mortars, Materials Science and Processing, Applied Physics 83 (2006)
685-688.

[34] I. Papayianni, Design of compatible repair materials for the restoration of monuments, International Journal for Restoration 10 (6) (2004) 623-636.

[35] I. Papayianni, V. Pachta, K. Iliadou, A data base system for managing information concerning historical mortars, in: International Conference on Virtual Systems and Multi Media (VSMM2008), Limassol, Cyprus, 2008.

[36] M. Stefanidou, I. Papayianni, V. Pachta, Evaluation of inclusions in mortars of different historic periods from Greek monuments, Archaeometry 54 (4) (2012) 737-751. 